\title{
Obsahová analýza minimálních preventivních programů základních škol se zaměřením na témata sexuální výchovy
}

\section{Content Analysis of the Minimal Prevention Programmes at the Czech Elementary Schools with Focus on the Topics of Sexuality Education}

\author{
Tereza Lubasová*, Miroslav Charvát, Kateřina Taranzová \\ Katedra psychologie, Filozofická fakulta, Univerzita Palackého v Olomouci
}

\begin{abstract}
Abstrakt
Cílem výzkumu je obsahová analýza minimálních preventivních programů na českých základních školách se zaměřením na témata sexuální výchovy. Byla použita kombinace kvalitativní a kvantitativní obsahové analýzy dokumentů. Analyzováno bylo 50 dokumentů s rozsahem 4-99 stran. Analýza témat, obsahu, typů realizovaných programů a evaluace byla komplikovaná nejednotnou terminologií a strukturou dokumentů a jejich obecností a př́liš širokým zaměřením. Nejčastěji uváděná témata zahrnovala otázky hygieny a péče o tělo (především u mladších ročníků), sexuální rizikové chování (u starších ročníků) a biologické rozdíly mezi pohlavími (napříč všemi ročníky). Ve 45 dokumentech nebyla zahrnuta témata sexu a médií, ve 39 chyběly informace o tom kde získat jakou pomoc. V 36 př́ípadech nebyla popsána témata sexuálního zneužíání ani vývoj zdravého sebepojetí žáků. Nejčastěji používanou metodou výuky bylo čtení $(\mathrm{n}=38)$ nebo frontální výklad $(n=29)$. Většinu dokumentů vytvořil školní metodik prevence $(n=26)$, v jiných př́padech byli do tvorby zapojeni další pedagogové. Celkově 41 škol uvádí, že nějakým způsobem evaluuje provedené programy (obvykle jde o nějakou blíže nespecifikovanou formu psané či ústní evaluace). Ve většině případů chyběl popis spolupráce s rodiči, resp. její ukotvení pro témata sexuální výchovy. Analyzované minimální preventivní programy jsou v otázkách sexuální výchovy prŕliš obecné. Nerozlišují mezi specifickou a obecnou prevencí a napřič školami se výrazně liší. Dokumenty naplňují formální požadavky, ale nejsou efektivním pomocníkem pro realizaci komplexní a efektivní prevence v oblasti sexuální výchovy na základních školách.
\end{abstract}

Kličová slova: minimální preventivní program, prevence, sexuální výchova, základní škola.

\section{Abstract}

The present study aims to analyse the content of minimal prevention programmes at Czech elementary schools, focusing on the topics of sexuality education.

\footnotetext{
* Korespondenční autorka: Tereza Lubasová, Katedra psychologie, Filozofická fakulta, Univerzita Palackého v Olomouci, Křŕžkovského 10, 77180 Olomouc, Česká republika.

E-mail: tereza.sadkova01@upol.cz
} 
A combination of quantitative content analysis and qualitative document analysis was used in the investigation of 50 documents, whose length ranged from 4 to 99 pages. The analysis of topics, content, methods of delivery and evaluation was complicated by non-uniform terminology and structure of the documents as well as their frequent ambiguity and non-specific, general scope.

Most commonly included topics covered the areas of personal hygiene and body care (mostly among younger pupils), sexual risk behaviour (mostly among older pupils), and biological sex differences (pupils of all ages). Forty-five of the documents did not include the topics of sex and media, 39 lacked information about where and how to get help. In 36 cases, the schools are not covering the topics of child abuse and neglect, nor the development of healthy self-esteem in their pupils. The most common methods of delivery were reading $(n=38)$ and lecture $(n=29)$. The documents were usually created by the school methodology specialists of primary prevention $(n=26)$ or other members of pedagogical staff. In total, 41 schools claimed that they evaluate their prevention programmes, usually in some form of oral or written feedback (mostly non-specified). However, most of them did not mention any poosibilities of school-parent cooperation, or it was not specified for the topics of sexuality education.

The analysed minimal prevention programmes are too general in the topics of sexuality education. They do not distinguish between specific and non-specific prevention, and vary across schools. While the documents comply with formal criteria, they are not suitable for the delivery of comprehensive and effective prevention in sexuality education at elementary schools.

Keywords: minimal prevention programme, prevention, sexuality education, elementary school.

\section{Úvod a cíle studie}

Každá škola (či školské zařízení) má za povinnost mít vypracovaný minimální preventivní program (dále též MPP) - klíčový dokument, podle kterého se řídí primární prevence na dané škole. MPP by měl být systematický a komplexní program, který bude dobře integrován do školního vzdělávacího programu a bude napomáhat žákům k dosažení (udržení) zdravého životního stylu a osobnostního rozvoje (MŠMT, 2010; Miovský, Skácelová, Čablová, Veselá, \& Zapletalová, 2012). Prevence rizikového sexuálního chování patří do oblasti všeobecné prevence, přesto výzkumy ohledně její realizace v českém školství spíše chybí (Sadková, 2018). Cílem našeho výzkumu tedy byla analýza témat a obsahů sexuální výchovy v MPP.

\section{Ukotvení sexuální výchovy v ČR}

\section{Sexuální výchova}

Sexuální výchova není v českém školství samostatným výukovým předmětem. Témata (obsah) sexuální výchovy najdeme v Rámcovém vzdělávacím programu (RVP - VÚP, 2005) v oblastech Člověk a jeho svět (1. stupeň ZŠ) a Člověk a zdraví (2. stupeň ZŠ). Vyučuje se obvykle v rámci předmětů Rodinná výchova a Výchova ke zdraví (Janiš, 2008). RVP mimo jiné sta- 
novuje i očekávané výstupy, které by měli žáci po dokončení určitého vzdělávacího období splňovat. Očekávané výstupy jsou dále rozpracovány ve Standardech pro základní vzdělávání Výchova ke zdraví (2013) a Standardech pro základní vzdělávání - Člověk a jeho svět (2013) do jednotlivých indikátorů doprovázených ilustrativními úlohami, dle kterých lze určit, zda bylo vzdělávání v dané oblasti úspěšné či nikoliv. Vzhledem k stručnosti RVP lze nahlédnout i do jiných dokumentů, které sice navrhují obsah sexuální výchovy vzhledem k věku vzdělávaného jedince, ale v České republice nejsou pro školy závazné (např. Standardy pro sexuální výchovu v Evropě, SPRSV, 2017).

Sexuální výchova má napomáhat $\mathrm{k}$ vytvoření přirozeného vztahu člověka ke svému tělu a k (vlastní) sexualitě, k prevenci sexuálního zneužívání dětí a dospívajících, zodpovědnému sexuálnímu chování, ke spojení sexuality s láskou, oddálení začátku sexuálního života, k orientaci v množství informací o sexualitě, omezení vlivu vrstevníků, posílení vztahu mezi rodiči a dětmi a k obecné spokojenosti v partnerském a sexuálním životě (Ketting, Friele, \& Michielsen, 2016; Šilerová, 2003). Dá se říci, že je to i výchova člověka ke zdravým hodnotám (Pelcová, 2013). V současné době již sex není tabuizován, žáci se dostávají častěji do styku s ním a s tématikou s ním spojenou. Jednou z prioritních snah pro model sexuální výchovy je uvádět na pravou míru informace získané z mimoškolních zdrojů (Janiš, 2008).

Sexuální výchova by měla být realizována na základě čtyř základních principů a s tím souvisejících cílů (Janiš, 2008; Jonášová, 2015): princip spolupráce rodičů a školy, princip vědeckosti, princip důvěry, princip vlastní aktivity a spolupráce s žákem. Provázanost spolupráce rodiny a školy v oblasti sexuality je žádoucí a nezbytná. Rodiče mnohdy ze strachu, že dítěti předají neadekvátní informace, nechávají informovanost dětí o sexualitě na škole a informace nesdělí. Tím se ale vytvoří kolem tématu tabu a dítě si informace hledá jinde - na internetu, u kamarádů apod., což s sebou nese určitá rizika (Jonášová, 2015). Pedagogové by měli rodiče informovat o obsahu, použitých metodách a cílech této výuky. Rodič může z osobních důvodů nesouhlasit $\mathrm{s}$ účastí dítěte na některém specifickém tématu sexuální výchovy, nicméně většina informací (např. anatomie rozmnožovacích orgánů, pohlavně přenosné choroby apod.) spadá do základního vzdělání každého člověka. Informace předávané vyučujícím by měly být objektivní a pravdivé. Metody musí odpovídat úrovni žáka a míře jeho poznání, zároveň i úrovni současného vědeckého poznání. Aby byly postoje, jevy a hodnoty žáků použitelné a trvalé, je nezbytné, aby byly identifikovány a interiorizovány. Toho lze dosáhnout tím, že budou žáci bráni jako spolutvưrci výchovy jich samých. Vzájemná spolupráce žáků pak napomáhá při tvorbě dovedností a chování (Janiš, 2008).

Kromě těchto čtyř principů můžeme také uvést podmínky či vlastnosti komplexní sexuální výchovy dle UNESCO (2018) platné nezávisle na tom, zda je sexuální výchova vyučována na školách či předávána jiným zpo̊sobem: vědecky přesná - založená na důkazech a výzkumech; návazná - začít v raném věku a postupně přidávat nové informace, které staví na informacích již dříve získaných; věku a vývoji přiměřená; ukotvená ve školních osnovách; ucelená (komprehensivní) - neomezená pouze na jeden (např. fyzický) aspekt sexuality a zároveň je ucelená ve své šíri a rozsahu vzdělávání (ne pouze jednotlivá lekce pro žáky bez předchozí návaznosti); založená na lidských právech - právo na vzdělávání, právo na zdraví atp.; založená na genderové rovnosti; relevantní pro danou kulturu a kontext; transformativní - posiluje jednotlivce i komunity, posiluje kritické myšlení a aktivní účast na veřejném životě; napomáhající rozvoji praktických dovedností, které umožňují zdravé rozhodování. 
Obdobné podmínky pro kvalitní sexuální výchovu kladou i Standardy pro sexuální výchovu v Evropě (SPRSV, 2017), z českých autorů pak např. Rašková (2008) či Šulová (in Šulová, Weiss, \& Fait, 2011). Všichni autoři kladou důraz na věkovou a vývojovou přiměřenost a vědecké ukotvení informací, většina z nich také postihuje nutnou komplexnost sdělení a pedagogické zdroje kladou důraz na vlastní aktivitu žáka. Vzhledem k značné otevřenosti RVP je na místě otázka, kde budou tedy vlastně témata sexuální výchovy ukotvená tak, aby mohla naplňovat minimálně zásadu o věkové a vývojové přiměřenosti informací? Domníváme se, že v českém prostředí může být tímto klíčovým dokumentem minimální preventivní program školy.

\section{Minimální preventivni program}

MPP je komplexní, systematický a dlouhodobý program, který je součástí školního vzdělávacího programu konkrétní školy či školského zařízení vycházející z rámcového vzdělávacího programu. Dle Ministerstva školství, mládeže a tělovýchovy (dále též MŠMT) i dle dalších odborníků je patrné, že MPP má svoje cíle a zásady, dle nichž by měl být vypracován a používán. MPP se zaměřuje na všeobecnou prevenci, resp. výchovu žáků ke zdravému životnímu stylu, na jejich osobnostní a emočně sociální rozvoj a na rozvoj jejich komunikačních dovedností (MŠMT, 2010; Miovský, et al., 2012).

Cílem MPP je zvyšovat schopnost žáků činit informovaná a zodpovědná rozhodnutí, podporovat zdravé sebepojetí, harmonickou rovnováhu tělesných a duševních funkcí, tělesné i duševní blaho. MPP vytyčuje a podporuje takové znalosti, dovednosti a způsobilosti (kompetence), které snižují, oddalují či blokují výskyt rizikového chování (MŠMT, 2010; Miovský, et al., 2012). Jednou z oblastí, na které se primární prevence dle MŠMT má prioritně zaměřit, je oblast rizikového sexuálního chování (MŠMT, 2010).

MPP je určený všem žákům ZŠ, jejich zákonným zástupcům a pedagogům, a dbá na vzájemnou spolupráci a vlastní aktivitu žáků. Program je zpracováván na jeden školní rok, v jehož průběhu by měl být doplňován a vyhodnocován, aby bylo na konci roku možné zhodnotit účinnost jeho realizace. Za podobu MPP je zodpovědný školní metodik prevence (koordinace př́íprav, kontrola realizace programu, vyhodnocení programu), na jeho tvorbě by se však měli podílet všichni pedagogičtí pracovníci školy (začlenění jednotlivých preventivních témat do výuky), ředitel školy (zodpovědnost za podporu, vytváření a realizaci programu), metodik prevence pedagogicko-psychologické poradny (zajištění odborné metodické pomoci ŠMP), krajský školský koordinátor (koordinace primární prevence na úrovni krajské koncepce) a organizace spolupracující se školou v daném regionu (Miovský et al., 2012). MPP definuje dlouhodobé a krátkodobé cíle školy. Přizpůsobuje se kulturním, sociálním či politickým okolnostem, složení obyvatelstva, finančním možnostem školy, obce či kraje, personálním i časovým možnostem (MŠMT, 2010).

Školy mají k dispozici literaturu, manuály a různá doporučení, jak MPP tvořit. Materiály však obsahují rozdílné informace a používají nejednotné pojmosloví. Struktura školami vytvořených MPP se tedy rovněž velmi liší (Žlabová, 2013; Institut pedagogicko-psychologického poradenství ČR, 2012).

Možnou podobu MPP nabízí např. Miovský et al. (2012). Vymezuje tři hlavní komponenty MPP (soubor pravidel bezpečnosti školy, programy zaměřené na rozvoj dovedností pro život a programy zaměřené na konkrétní formy rizikového chování). Celková časová dotace např́ič celou základní školou by měla činit okolo 86 hodin, z nichž 30 hodin náleží dovednostem pro 
Život a 56 hodin části zaměřující se na konkrétní typy rizikového chování. Návod na sestavení MPP nabízí také metodická příručka pro specializační studium pro školní metodiky prevence (Macková \& Skácelová, 2012).

Konkrétní uspořádání dokumentu se pak liší v závislosti na výchozím manuálu. Pražské centrum primární prevence (2010) ve shodě s Miovským et al. (2012) např́íklad uvádí následující stavbu dokumentu: charakteristika školy a její vnitřní zdroje, vnější zdroje školy, cíle MPP, skladba aktivit MPP pro jednotlivé cílové skupiny - žáci, učitelé, rodiče, dokumentace další součásti MPP (v rámci dokumentu či formou př́loh) - evaluace, zápisy z programů, legislativní podklady týkající se prevence, kontakty aj.

Konkrétní informace o zařazení témat sexuální výchovy do MPP jsme nalezli pouze v dokumentu od Miovského et al. (2012), kde je dán návrh rozvržení hodin výuky věnovaných sexuálnímu rizikovému chování v celkovém rozsahu 7 hodin za 9 ročníků ZŠ. Výhodou je navrhované rozdělení znalostí, dovedností a kompetencí v rámci těchto témat. Zde podotkněme, že sexuální rizikové chování tvoří jen část obsahu kvalitní a komplexní sexuální výchovy.

\section{Výzkum}

\section{Cíle výzkumu}

Cílem našeho výzkumu bylo analyzovat MPP se zaměřením na témata sexuální výchovy. Tento cíl upřesňují následující výzkumné otázky:

1. Jakou mají obecně sledované MPP strukturu a kvalitu?

2. Kolik prostoru je v MPP věnováno sexuální výchově, tj. jakou hodinovou dotaci a jaké rozložení v rámci jednotlivých ročníků má?

3. Jaká témata týkající se sexuální výchovy jsou v MPP zmiňována a akcentována?

4. Jaké metody realizace či předávání jsou s ohledem na sexuální výchovu voleny a jak jsou evaluovány?

5. Jaká další specifika vykazuje téma sexuální výchovy ve sledovaných MPP?

\section{Metody}

S ohledem na stanovený cíl a výzkumné otázky studie jsme zvolili kombinaci kvantitativní obsahové analýzy a kvalitativní tematické analýzy znění dokumenti̊. Výhodou této metody je nemožnost dalšího zkreslení analyzovaných dokumentů probandy. Obsahovou analýzu lze úspěšně kombinovat s jinými metodami (Beck \& Manuel, 2008). Pomocí obsahové analýzy jsme posuzovali základní obsahové a formální charakteristiky, významy a témata, která se vyskytují ve zkoumaných MPP. Dokumenty byly opakovaně podrobně pročítány a do připravené tabulky byly poté zaznamenávány jejich jednotlivé parametry (např́klad dichotomické vyjádření prrítomnosti či nepřítomnosti příznaku 0/1, jiné číselné vyjádření uvedené kvantity nebo zhodnocení dílčího znaku na předem definované škále). Jednotlivé body analýzy či hodnocené parametry jsme volili s ohledem na cíle výzkumu a předchozí teoretická doporučení $\mathrm{k}$ vytváření MPP (zejména pak standardy uvedené v bodě 2.1 a doporučení pro tvorbu MPP v bodě 2.2 teoretických východisek studie). V př́padě kvantitativních znaků šlo konkrétně např́iklad o: rozsah celého dokumentu, celkovou časovou dotaci na prevenci a časovou dotaci pro jednotlivá témata $\mathrm{v}$ rámci ročníků. Výsledné souhrny jsme se poté snažili co nejlépe vizualizovat pomocí 
tabulek a grafư, které pojmou větší množství informací, sáhli jsme tak i k méně obvyklé formě prezentace pomocí ikonického grafu.

Kvalitativní znaky, které uvedené dokumenty vykazovaly, jsme analyzovali pomocí kvalitativní analýzy dokumentů, jak ji definuje např́klad Miovský (2006). Výhodou je opět dobrá kombinovatelnost tohoto prístupu, ale především i možnost postřehnout i specifické aspekty, které by jinak ušly pozornosti. Opakovaně jsme pročítali získané dokumenty, přičemž jsme si dělali detailní poznámky spojené s hodnoceným obsahem, kódovali jednotlivé úryvky textu a následně svá zjištění přenesly v kondenzované podobě pomocí stručných slovních vyjádření nebo předem definovaných hodnotících škál opět do připravených tabulek. Hodnotili jsme tak například výskyt těchto fenoménů: mechanického kopírování pasáží v rámci dokumentu z minulých MPP či z dokumentů MŠMT, detailnost popisu typů používaných programů, uvedené metody evaluace a měřitelnost stanovených cílů preventivních aktivit, definovaní cílových skupin programů, zmiňovaná témata sexuální výchovy, popis spolupráce s externími organizacemi a kontakty na ně, přehlednost a úplnost struktury celého dokumentu, návodnost a možnosti praktického využití daného MPP, užití odborného jazyka či celkově konkrétnost a srozumitelnost textů.

Kvalitativní postup se nakonec v mnoha ohledech ukázal jako nezastupitelný, nebot' dokumenty nebyly zdaleka tak strukturované, jak je doporučováno či jak by bylo žádoucí, a neobsahovaly ani jednotnou či jasně definovanou terminologii. Výsledky obou postupů prezentujeme dohromady, protože ve výsledkové části sledujeme spíše logiku tematického řazení dle položených výzkumných otázek.

\section{Výběrový soubor}

Statistickými jednotkami v této analýze jsou dokumenty MPP vytvořené ZŠ v České republice (dále i ČR). Teoreticky by měl být tento dokument vypracován každou ZŠ a být veřejně dostupný, tj. základní soubor všech těchto MPP tedy potenciálně činní 4115 ZŠ/MPP v ČR (MŠMT, 2016). Pro naši analýzu jsme se rozhodli použít výběrový soubor o velikosti 50 MPP, což činí 1,22 \% ze základního souboru. Tabulka 1 uvádí počty Z $\breve{S}$ v ČR, přepočet absolutního zastoupení MPP z každého kraje pro soubor o velikosti N=50 a reálné zastoupení MPP z jednotlivých krajů v našem výběrovém souboru. Snažili jsme se tyto krajové kvóty v našem výběrovém souboru dodržet, abychom se vyhnuli případnému zachycení pouze regionálních specifik. Původním záměrem bylo MPP (resp. ZŠ) vybírat náhodně dle seznamu škol MŠMT, nicméně tímto postupem nebylo možné efektivně získat potřebný počet MPP - značná část ZŠ vybraných tímto způsob neměla MPP zveřejněný v elektronické podobě na webu školy. Změnili jsme proto strategii výběru a v rámci daných krajů jsme náhodně vybírali pouze města, a poté jsme konkrétní MPP vybírali již účelově, konkrétně jsme do internetového vyhledávače zadávali kombinaci klíčových slov „minimální preventivní program“, „základní škola“ a název příslušného města v kraji.

Sledované školy měly od 19 do 1053 žáků s průměrem 355 a mediánem 289 žáků. V souboru se vyskytlo pět alternativních, jedna speciální a 44 běžných základních škol. Malotřídních škol se sloučenými ročníky bylo sedm, pouze první stupeň měly čtyři školy a zbylých 39 škol bylo plně organizovaných s devíti ročníky. Bližší specifikace škol z etických důvodů neuvádíme. Uvedené školy nebyly informovány o skutečnosti, že jejich MPP se staly objektem této studie. 
Tabulka 1 Reprezentativní zastoupení MPP v souboru dle reálného rozložení v populaci ČR

\begin{tabular}{llll}
\hline Kraj: & $\begin{array}{l}\text { Zastoupení } \\
\text { ve výběrovém } \\
\text { souboru }\end{array}$ & $\begin{array}{l}\text { Ideální zastoupení } \\
\text { dle populace }\end{array}$ & $\begin{array}{l}\text { Populace Ž́ } \\
\text { v absolutních } \\
\text { počtech }\end{array}$ \\
\hline Hlavní město Praha & 3 & 3,2 & 265 \\
\hline Středočeský & 6 & 6,5 & 534 \\
\hline Jihočeský & 3 & 3,1 & 255 \\
\hline Plzeňský & 3 & 2,7 & 220 \\
\hline Karlovarský & 1 & 1,3 & 106 \\
\hline Ústecký & 3 & 3,4 & 280 \\
\hline Liberecký & 3 & 2,5 & 205 \\
\hline Královéhradecký & 3 & 3,3 & 268 \\
\hline Pardubický & 3 & 3,0 & 250 \\
\hline Vysočina & 3 & 3,2 & 263 \\
\hline Jihomoravský & 6 & 5,7 & 473 \\
\hline Olomoucký & 4 & 3,6 & 296 \\
\hline Zlínský & 4 & 3,1 & 258 \\
\hline Moravskoslezský & 5 & 5,4 & 442 \\
\hline CELKEM & $50(1,22 \%)$ & 50 & $4115(100 \%)$ \\
\hline
\end{tabular}

\section{Výsledky - odpovědi na výzkumné otázky}

\section{Jaká jsou formální vlastnosti sledovaných MPP?}

Sledované MPP měly rozsah počtu stran v poměrně velikém rozpětí od čtyř do 99 . Průměrný počet stran byl 21,5 a medián pak 18. V 26 případech byl autorem MPP pouze školní metodik prevence, $v 15$ bylo uvedeno více autorů ze sboru a ve zbylých devíti př́ípadech nebyl autor vůbec dohledatelný. Pět MPP obsahovalo pasáže přímo vykopírované (bez úprav) z materiálů MŠMT, ve čtyřech MPP se objevilo kopírování v rámci dokumentu (kopírování stejného textu pro různá témata a oblasti, tj. nespecifičnost plánů). V 31 př́padech nebyl uveden MPP z minulého roku, nebylo tedy možné provést srovnání, zda je MPP připraven specificky na aktuální školní rok či zda jde o obecný dokument kopírovaný z roku na rok.

Delší dokumenty byly většinou i přehlednější, přesnější a lépe se analyzovaly. Kratší (konkrétně velmi krátké dokumenty) byly spíše chaotické, neuspořádané, velmi obecné a mnohdy tzv. „nic neříkající،. Také se objevovaly MPP, kde rozsáhlou část dokumentu tvořily krizové plány školy, ale ,jádro“ MPP bylo neúplné. Přehlednosti MPP by jednoznačně pomohlo zavedení jednotné terminologie a struktury, či alespoň dodržování stejných zásad při tvorbě dokumentu (např. zda je dokument řazen tematicky nebo dle ročníků).

Kolik prostoru je v MPP věnováno sexuálni výchově, tj. jakou hodinovou dotaci a jaké rozložení v rámci jednotlivých ročníků má? Jaká témata týkajicí se sexuální výchovy jsou v MPP zmiňována a akcentována?

Tyto dvě otázky jsme se nakonec rozhodli sloučit do jednoho tematického bloku a poskytnout tak ucelenější přehled. Samotnou obsahovou analýzu provázelo několik nesnází, které se nejprve pokusíme popsat, než přejdeme k vlastní prezentaci grafů a tabulek. 
Ačkoliv manuály k tvorbě MPP pojmenovávají a vymezují probíraná témata $\mathrm{v}$ jednotlivých ročnících i umístění v rámci MPP, ve zkoumaných dokumentech byly informace k námi zkoumané oblasti sexuální výchovy chaoticky rozmístěné v celém dokumentu. Často nebylo patrné, jaké akce jsou zaměřené, na jaké rizikové chování, popř. nebylo zřejmé, zda (či jak) může naplnění cílů sexuální výchovy přispět např. obecně uváděný adaptační pobyt.

Při analýze konkrétních témat se jako problematická ukázala terminologie, resp. přesnost označení jednotlivých témat - zatímco některé školy uváděly témata relativně přesně (př. ,,potraty“), jiné se spokojily s obecným označením (př. ,„možnosti plánování rodičovství“), bylo tedy při samotné analýze nutné zkoumané kategorie značně slučovat. Není možné určit, zda prŕípadné obecné kategorie obsahují vše, co je napsané v RVP či v jiných dokumentech. Míra obecnosti byla problémem i při určování ročníkủ, kdy jsou jednotlivá témata probírána, protože část škol uváděla „průřrezově“, či „druhý stupeň“. V prř́padě, že škola uvedla první či druhý stupeň, do analýzy to bylo zavedeno jako probírání tématu v každém ročníku daného stupně, což nemusí odpovídat reálné situaci. Obecně nejčastějším tématem byly návykové látky v souvislosti se vztahy žáků. Naopak nejméně časté je zařazení témat souvisejícím se sexem a médii, což lze vzhledem ke snadné dostupnosti pornografie, diskuzi o zobrazování (především ženských) těl v módních časopisech a rozšířenosti elektroniky považovat za alarmující. Zařazení témat dle jednotlivých ročníků ukazuje tabulka 2. Přestože bylo snahou autorů nalézt odpověd' na otázku př́padné hodinové dotace pro jednotlivá témata, tyto informace nebyly v analyzovaných MPP dostupné.

Tabulka 2 Počty škol $(\mathrm{N}=50)$, které dané preventivní téma zařazují do jednotlivých ročníků

\section{Témata:}

návykové látky

hygiena a péče o tělo

rizikové sex. chování a jeho důsledky

biologické rozdíly mužů a žen

rasismus, náb. nesnášenlivost, xenofobie

změny psychické a fyzické

týrání a zneuživání

zdravé sebepojetí (psych.i fyz.)

kam se obrátit pro informace a pomoc

sex a média (internet a TV)

1.r. 2. r. 3. r. 4. r. 5. r. 6. r. 7.r. 8. r. 9. r.

\begin{tabular}{|c|c|c|c|c|c|c|c|c|}
\hline & & & & & & & & \\
\hline 12 & 15 & 16 & 17 & 17 & 18 & 17 & 14 & 15 \\
\hline 15 & 11 & 12 & 11 & 11 & 7 & 5 & 5 & 6 \\
\hline 0 & $\mathbf{0}$ & 3 & 4 & 5 & 8 & 11 & 18 & 21 \\
\hline 4 & 7 & 9 & 10 & 9 & 10 & 5 & 7 & 6 \\
\hline 0 & 1 & 8 & 8 & 8 & 10 & 11 & 11 & 10 \\
\hline 3 & 5 & 10 & 9 & 7 & 8 & 4 & 4 & 2 \\
\hline 4 & 5 & 7 & 4 & 6 & 7 & 7 & 7 & $\mathbf{0}$ \\
\hline 1 & 1 & 3 & 3 & 6 & 11 & 7 & 7 & 5 \\
\hline 4 & 5 & 5 & 2 & 5 & 3 & 2 & 5 & 4 \\
\hline 2 & 1 & 1 & 1 & 1 & 1 & 2 & 2 & 3 \\
\hline
\end{tabular}

V MPP nebyla respektována doporučovaná struktura při popisu akcí zajišt’ovaných externími organizacemi (toto bylo pouze u minimálního počtu dlouhých a propracovaných dokumenti̊). Taktéž se často objevila informace, že další program školy, návštěvy externích odborníků atp. budou průběžně zveřejňovány dle aktuální nabídky, ale ani v jednom případě nebylo možné tyto informace na webu školy dohledat (pouze ex post ve výroční zprávě školy). Nelze tedy zjistit, jaká témata byla v rámci těchto externích přednášek či jiných akcí poskytována. Tam, kde byla tato informace uvedena, byla zanesena do př́slušného probíraného tématu. Identifikovaná témata naleznete $\mathrm{v}$ grafu 1 . 
Graf 1 Témata sexuální výchovy v rámci zkoumaných MPP

sex a média (internet a TV)

kam se obrátit pro informace a pomoc

týrání a zneužívání

zdravé sebepojetí (psych. i fyz.)

rasismus, náb.nesnášenlivost, xenofobie

hygiena a péče o tělo

změny psychické a fyzické

sex. rizikové chování a jeho důsledky

biologické rozdíly mužů a žen

návykové látky

nemá

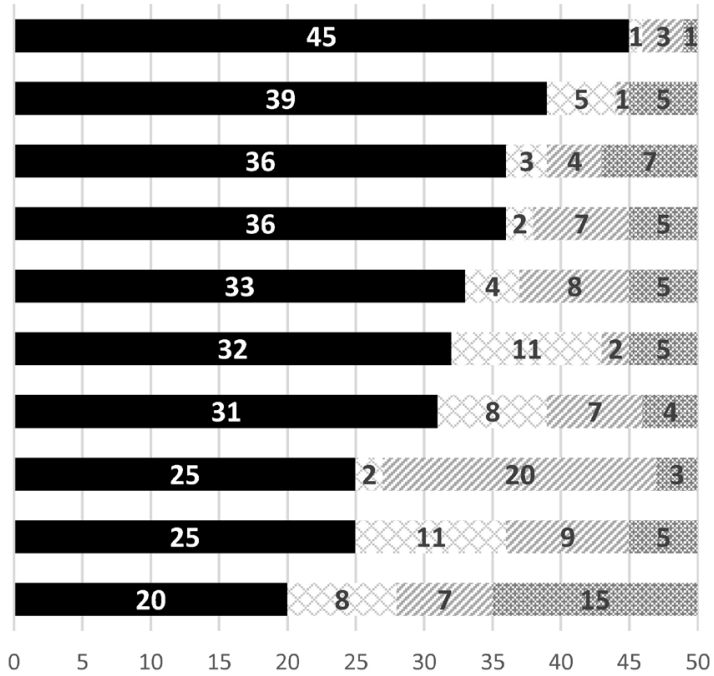

\& má pouze na 2 . st

má na obou stupních

Grafické zobrazení založené na principu Chernoffových tváří (graf 2) umožňuje přehledné vizuální uchopení všech 50 analyzovaných MPP z hlediska uvedení př́slušných témat. Pro lepší pochopení významu grafu s Chernoffovými tvářemi uvádíme ještě tuto tabulku $3 \mathrm{~s}$ modelovými př́klady.

Graf 2 Chernoffovy tváře zobrazující probíraná témata z oblasti zdravých vztahů v jednotlivých ZŠ
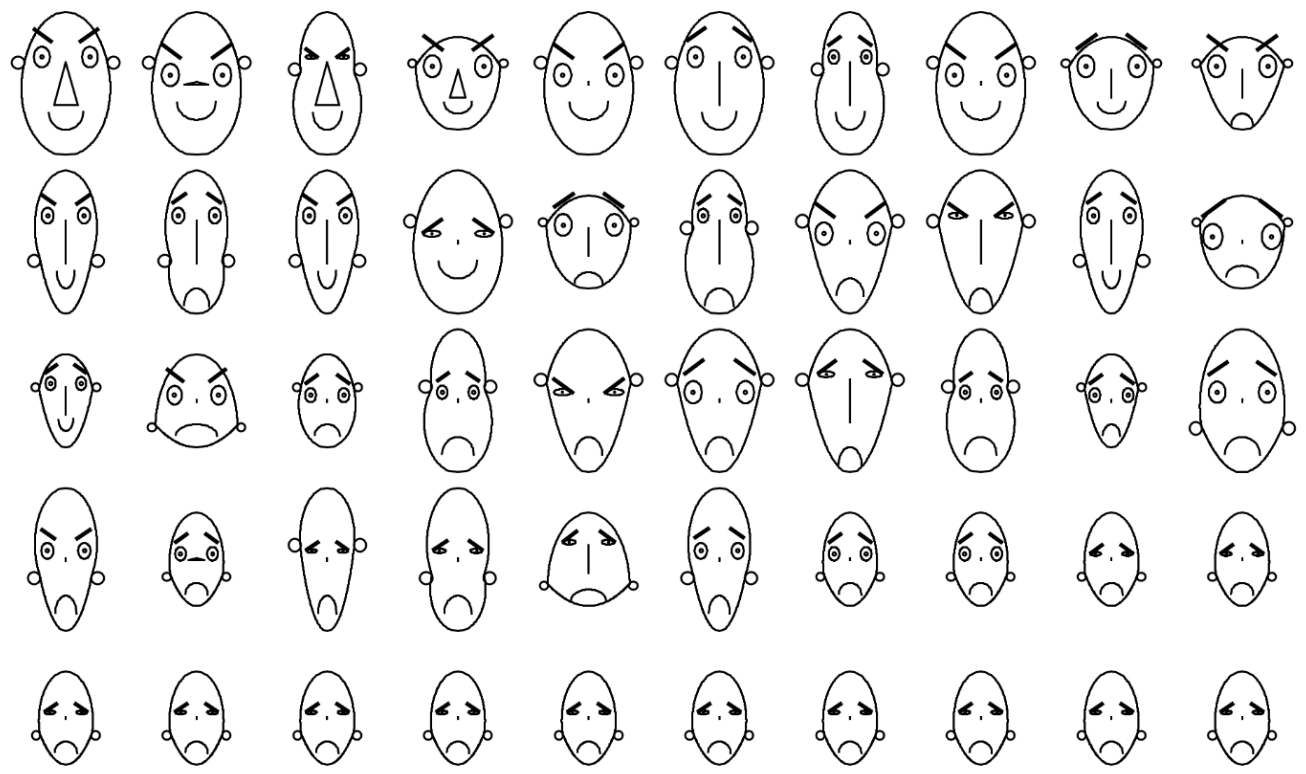

Pozn.: široký obličej = psychické a fyzické změny; vysoký obličej = sexuální rizikové chování; plnost tváří = hygiena a péče o tělo; úsměv = prevence týrání a zneuživání dětí; velké oči = návykové látky; sebevědomé obočí = 
zdravé sebepojetí; uši nahoře = pohlavní biologické rozdíly; veliké uši = informace o možnostech pomoci; dlouhý nos = rasismus, xenofobie; široký nos = sex a média (internet, TV).

Tabulka 3 Př́iklady zobrazení nejobsažnějšího a nejslabšího MPP

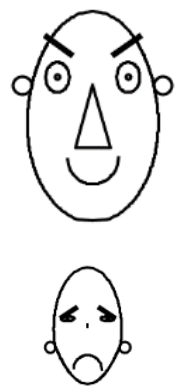

Tento MPP (resp. tato škola) uvádí nejvíce témat souvisejících s problematikou sexuální výchovy a výchovy ke zdravým vztahům. Konkrétně jde o tato témata: psychické a fyzické změny, sexuální rizikové chování, hygiena a péče o tělo, prevence týrání a zneužívání, návykové látky, zdravé sebepojetí, pohlavní biologické rozdíly, informace o možnostech pomoci, rasismus a xenofobie, sex a média (internet, TV).

Tento MPP (resp. tato škola) neuvádí konkrétně žádné z témat souvisejících s problematikou sexuální výchovy a výchovy ke zdravým vztahům.

Jaké metody realizace či predávání jsou s ohledem na sexuálni výchovu voleny a jak jsou evaluovány?

Jako nejčastější metoda realizace prevence byl volen výklad či přednáška. Jak je patrné z grafu 3, MPP ani v tomto prípadě neměly jednotnou terminologii, lze se tak jen domnívat, zda např. často uváděný „,blok primární prevence“ obsahoval skupinovou práci, přednášku, či zda byl shodný s tím, co jinde nazývaly jako „,beseda“. Z tohoto důvodu nebyly tyto kategorie (byt' se mnohé z nich jistě překrývají) dále slučovány. V ojedinělých př́ípadech se stávalo, že byl uveden název akce, ale bez určení formy realizace, nebylo tedy možné toto hodnotit.

Graf 3 Metody realizace

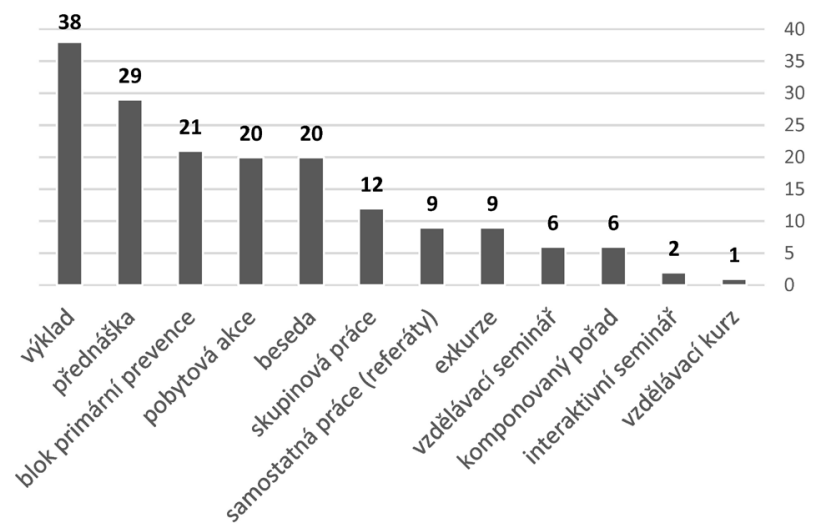

Graf 3 Metody realizace

Nějakou metodu evaluace provedených programů uvádělo 41 škol, 9 škol žádnou metodu evaluace provedeného programu neuvedlo. Obvykle uváděly 2 metody evaluace, maximálně 4. Nejčastější formou evaluace je „písemná zpětná vazba“ (n=36) a „ústní zpětná vazba“ (n=35). $\mathrm{V}$ těchto kategoriích jsou zahrnuty např. zpětnovazebné dotazníky či diskuze na třídnických 
hodinách. Některé MPP uvedly využití schránky důvěry $(n=19)$ či (blíže neupřesněné) využití žákovského parlamentu $(\mathrm{n}=12)$. V 20 MPP bylo uvedeno, že o evaluaci programů prevence žádají také rodiče a dle 29 MPP se na evaluaci podílejí také pedagogové.

Jaká dalši specifika vykazuje téma sexuální výchovy ve sledovaných MPP?

Jednoznačnou cílovou skupinou, na kterou bylo cíleno všech 50 MPP, jsou žáci. Někdy jsou jako cílové skupiny MPP uváděni rodiče $(n=29)$, či pedagogové $(n=28)$. Velmi obtížné bylo analyzovat spolupráci rodičů se školou v oblasti sexuální výchovy - v dokumentech, kde byla zahrnuta spolupráce s rodiči, byla uvedena pouze obecná informace o způsobu komunikace s rodiči (př. třídní schůzky), ale již bez informace o tom, zda je toto realizováno i pro témata sexuální výchovy. V několika případech byla také jako forma spolupráce rodičů se školou uvedena společná akce (př. Drakiáda) - zde lze pochybovat, zda by tato akce mohla být využita pro spolupráci či alespoň informovanost rodičů o prevenci rizikového sexuálního chování na škole. Výjimečně byla uvedena konkrétní akce, na které byli rodiče informováni o problémovém tématu, ale bez výjimky se jednalo o akce zaměřené na drogovou prevenci či netolismus, tj. nesouvisející se sexuální výchovou.

Mezi nejčastější spolupracující organizace je uváděna Policie České republiky $(n=30)$ či Městská policie $(\mathrm{n}=28)$, méně časté je zapojení místního Orgánu sociálně právní ochrany dětí $(\mathrm{n}=19)$. V téměř polovině případů $(\mathrm{n}=24)$ bylo v MPP uvedeno, že škola využívá spolupráce s jinou organizací, z toho nejčastěji $(n=16)$ šlo o zapojení pedagogicko-psychologické poradny. Jako příklady dalších organizací, se kterými škola na prevenci spolupracuje, jsou napřr. střediska výchovné péče, krizové linky či místní neziskové organizace (Semiramis, Maják, ACET, atp.). V př́padězapojeníjednotlivýchorganizacínebylovždymožnéurčit,zdajdeoorganizacizapojenou do prevence rizikového sexuálního chování, či organizaci zapojenou v rámci prevence v jiných oblastech (v mnoha případech jde navíc o tematické propojení - např. u prevence HIV/AIDS).

Nejčastěji v MPP chyběly kontakty, na koho se v př́padě potřeby obrátit. Kontakty byly obvykle uvedené průběžně $\mathrm{v}$ dokumentu, nikoliv na závěr samostatně. V několika př́ípadech také nebyly kontakty uvedeny, ale byl uveden pouze odkaz na webovou stránku organizace či odkaz na jinou stránku školy.

Mezi pozitivními př́klady a zároveň možnou inspirací do praxe lze uvést následující nalezené aktivity: odebírání časopisu Prevence, zavedení preventivní nástěnky, kde jsou formou piktogramů uvedené postupy prevence a odpovídající kontakty, či odkazy na preventivní videa uvedené př́ímo $\mathrm{v}$ MPP.

\section{Diskuze}

Výzkumy týkající se analýzy obsahu MPP jsou ojedinělé a bývají součástí závěrečných prací studentů pedagogických oborů. Dostupné výzkumy se zabývají obecně MPP bez zaměření na oblast sexuální výchovy.

Z našeho výzkumu je zřejmé, že MPP se mezi sebou výrazně liší v mnoha aspektech, což potvrzují i další sondy do této problematiky. Jedním z výzkumů, který se věnuje analýze MPP jako takových, je sonda Pečinkové (2011), která ale pracovala pouze s informacemi od třech metodiků prevence (rozhovory) a analýzou evaluačních zpráv. Vzhledem k malému rozsahu 
výzkumu a jeho formě šlo spíše o zjištění individuálních specifik než srovnání většího počtu př́ípadů. I zde ale můžeme pozorovat výrazné rozdíly mezi jednotlivými školami.

Rozsáhlejší soubor měl k dispozici Čepa (2014), který pracoval s 14 MPP, všechny z jednoho kraje. Získané MPP analyzoval s ohledem na jejich strukturu tak, jak ji uvádí Skácelová (2010, in Čepa, 2014). Opět je jeho závěrem konstatování, že MPP se mezi jednotlivými školami výrazně liší, a to jak obsahem, tak formálními charakteristikami.

Manuály k tvorbě MPP (př. Miovský et al., 2012) pojmenovávají a vymezují dílčí témata v jednotlivých ročnících (co kdy probírat) a minimálně částečně uvádí, jak má být MPP strukturován (co kam napsat). Provedení reálných analyzovaných MPP je ovšem značně odlišné struktura obsahu je různorodá, informace jsou často chaoticky rozeseté po celém dokumentu. Kromě struktury se výrazně liší i rozsah dokumentu a míra jeho obecnosti - některé MPP jsou velmi konkrétní jak v tématech, tak v kontaktech, aktivitách a metodách, častější jsou ale MPP s vágními a strohými informacemi. Lze jistě namítat, že pokud by byl dokument MPP psaný př́liš odborným jazykem, pak by mu nemusela rozumět řada jeho adresátů, tj. zejména rodičů žáků, nicméně i odborná stránka věci se dá popsat srozumitelně a v popularizačním stylu při zachování nutného minima důležitých informací. Nemusíme tedy např́ílad uvádět, že: „Efektivita přednášky v rámci specifické všeobecné prevence sexuálního rizikového chování adolescentů o pohlavně prenosných chorobách vedené externím lektorem (venerologem) je měřna na základě množství a kvality kličových informací, které si žáci udrželi v dlouhodobé paměti alespoň 2 měsice po realizaci prednášky, pomoci dotazníku o 20 položkách využivajícího kombinaci testových otázek s vícenásobnou volbou a jednou správnou odpovědi a postojové škály s položkami Likertova typu.“, stačilo by v prř́slušné pasáži MPP uvést, že: „Preventivni dopad všech přednášek spolupracujícich externisti̊ je vyhodnocován pomoci anket mezi žáky zaměřných na jejich znalosti a postoje $k$ dané problematice s odstupem dvou mésíců od realizace prednášky“. Pokud je ovšem MPP natolik obecný a nekonkrétní, že v něm tyto informace bud' zcela chybí nebo jsou jen vágně pospány ve stylu: „Preventivní aktivity celé školy pravidelně vyhodnocujeme s kolegy v rámci školniho poradenského pracoviště.“, pak je jeho informační prŕnos mizivý pro jakéhokoliv čtenáře.

Nejčastěji je MPP tvořen z větší části krizovým plánem školy. Lze odhadovat, že školy mají nejspíš lépe zpracované právě krizové plány, ke kterým je více návodů, manuálů, vzorů apod., takže tím mohou zaplnit místo v MPP. Vzhledem k tomu, že většina škol neměla uvedený MPP z předchozích let, nebylo možné určit, nakolik jsou MPP specifické v daném roce, nebo zda byly pouze překopírovány z let minulých.

Ačkoliv by se na tvorbě MPP měl podílet celý tým odborníků, v naší analýze se toto dělo pouze $\mathrm{v}$ menším počtu případů $(\mathrm{n}=15)$, v 9 případech nebyl autor vůbec uveden, není tedy možné toto posoudit. Rozdíly v autorech MPP zjistila ve svém výzkumu i Pilařová (2011), která upozorňuje na paradox, kdy v některých případech je autor jeden a v jiných se podílí naopak téměř celý pedagogický sbor.

Celková časová dotace na prevenci na škole byla uvedena pouze u 6 MPP, přičemž byla v rozsahu 13 až 80 hodin ročně, s průměrem 57 hodin ročně. Toto nedosahuje doporučení uvedených např. Miovským et al. (2012) o vhodném počtu asi 86 hodin ročně, ale může být odpovídající pro doporučených 56 hodin zaměřených na konkrétní typy rizikového chování.

Obecně doporučováno je volit pro předání informací ty pedagogické metody, které umožňují aktivní zapojení žáků do výuky, přesto byl nejčastěji uváděnou metodou výklad, resp. přednáš- 
ka. U dalších metody bylo možné určit, zda či do jaké míry jde o metody s aktivním zapojením žáků (př. blok primární prevence lze realizovat jako skupinové aktivity či jako přednášku). V MPP jsou uváděny i aktivity, jejichž př́nos prevenci je spíše obecný (škola v přírodě, lyžařský výcvik apod.). Tyto akce sice mohou při dobrém vedení přispívat formování kolektivu (tedy učit toleranci, respektu a dalších hodnot), ale bližší určení těchto akcí není možné. V řadě MPP tyto nespecifické aktivity převažují, naopak specifické aktivity výrazně chybí.

Diskutabilní jsou uvedené metody evaluace - v některých případech je uvedena např. „,fotodokumentace“ či ,zápis v třídní knize“, což jsou aktivity, které lze jen těžko považovat za ty, které mají potenciál pro kvalitní evaluaci. Podobně definované evaluační ukazatele nejsou nijak ověřitelné nebo měřitelné, a nejde proto na jejich základě ani získávat zpětnou vazbu o úspěšnosti preventivních snah. Problematickou evaluaci činností v MPP se ve své práci zabývá i Neuwirth (2012), který konstatuje chybějící evaluační metodologii, což ho vedlo k tvorbě Návrhu metodologie a nástrojů pro evaluaci MPP (pro Jihočeský kraj). Chybějící evaluaci MPP zjistil i Čepa (2014). V doporučeních pro tvorbu a realizaci MPP je uvedeno, že MPP by měl být vždy každý rok vyhodnocen a aktualizován - vzhledem k tomu, že u některých dokumentů se objevovalo kopírování částí textu, a protože nebyly MPP z minulých let dohledatelné, lze se domnívat, že dochází ke kopírování stejného materiálu, popř. s minimálními úpravami. Toto lze opět dávat do souvislosti s nefunkční evaluací, která tím pádem neplní svoji formativní funkci. Dle Pilařové (2011) je úprava tématu pro další rok většinou založené spíše na odhadu jeho tvůrců, než na systematické evaluaci dosavadních akcí.

Spolupráce rodiny se školou se po provedené analýze ukazuje jako značně nedostatečná a spíše omezená na nutné předání informací.

$\mathrm{Z}$ analýzy MPP lze celkově zhodnotit, že ve většině případů tvoří MPP pouze povinný dokument, který byl vytvořen jako „,nutné zlo“. Pouze malé množství analyzovaných dokumentů lze pokládat za prakticky využitelné a pravděpodobně skutečně realizované.

Nevýhodou zvolených metod je fakt, že obsah MPP nemusí nutně odpovídat reálné kvalitě skutečné realizace primární prevence zaměřené na sexualitu a vztahová témata na dané škole. Může se to dít v obou směrech. MPP může být sice nekvalitní, nicméně samotná práce s žáky může být na dobré úrovni. Na druhou stranu ani obsahově kvalitně zpracovaný MPP nemusí zároveň znamenat i kvalitní poskytování této formy specifické prevence žákům. Spíše se ale kloníme k názoru, že analyzované MPP mohou svým obsahem o míře systematičnosti v poskytování potřebné edukace vypovídat poměrně dobře, nebot' právě na základě těchto dokumentů by se měly preventivní aktivity řídit a realizovat.

Výběrový soubor dokumentů nemusí být zcela reprezentativní, protože nešlo o čistě náhodný výběr a pouze dodržení krajových kvót nemusí tuto slabinu zcela odstranit. Svou těžko kontrolovanou roli mohly sehrát i vyhledávací algoritmy použitých internetových vyhledávačů. $\mathrm{Na}$ druhou stranu vzorek 50 dokumentů již není úplně malým a míra nedokonalostí je v něm i tak poměrně značná.

\section{Závěry}

Nejčastější chybou v analyzovaných MPP byla výrazně nejednotná terminologie, a to ve všech částech MPP (metody výuky, obsahy atp.). Odlišná terminologie byla používána nejen v různých 
MPP, ale i v rámci jednoho dokumentu. Další obtíží je přílišná obecnost programu - chybí zde jednoznačně zakotvená témata, časové dotace, harmonogram realizace prevence i specifické metody evaluace. Evaluace byla ve všech zkoumaných dokumentech nejméně specifická a často přehlížená. Obecnost a nespecifičnost všech zmíněných částí MPP je zvláště zjevná při srovnání s jinými oblastmi prevence (př. šikana, drogy), na které je již delší dobu kladen důraz. V analyzovaných MPP byly často opomíjeny rozdíly mezi specifickou a nespecifickou prevencí - např. obecné adaptační pobyty byly stavěny na roveň besedě o prevenci HIV/AIDS. Celkově lze dokumenty hodnotit jako spíše naplnění formálních podmínek než jako poklady pro praktickou činnost.

\section{Grantová podpora}

Př́spěvek vznikl za podpory MŠMT, grant IGA_FF_2017_002 - Evaluace současného stavu sexuální výchovy na základních školách v České republice.

\section{Reference}

Beck, S. E., \& Manuel, K. (2008). Content analysis: Practical research methods for librarians and information professionals. New York: Neal Schuman Publishers.

Čepa, M. (2014). Školní metodik prevence a tvorba minimálnich preventivních programů na základnich školách v Olomouci. (Nepublikovaná diplomová práce). Olomouc: Univerzita Palackého v Olomouci.

Institut pedagogicko-psychologického poradenství ČR. (2012). Analýza minimálních preventivních programů škol zapojených do projektu Rozvoj ŠPP-VIP I. Získáno 7. února 2018 z www.ippp.cz/rspp/images/vystupy/mpp.doc

Janiš, K. (2008). Učební text k problematice rodinné a sexuální výchovy. Hradec Králové: Gaudeamus.

Jonášová, I. (2015). Priloha_18_Riziikove_sexualni_chovani.doc. Získáno 7. února 2018 z http://www.msmt.cz/vzdelavani/socialni-programy/metodicke-dokumenty-doporuceni-apokyny

Ketting, E., Friele, M., \& Michielsen, K. (2016). European Expert Group on Sexuality Education. Evaluation of holistic sexuality education: A European expert group consensus agreement. The European Journal of Contraception and Reproductive Health Care, 21(1), 68-80. https://doi.org/10.3109/13625187.2015.1050715

Macková, L., Skácelová, L. a kol. (2012). Specializačni studium pro školní metodiky prevence metodická přiručka. Praha: Univerzita Karlova v Praze \& Togga.

Miovský, M. (2006). Kvalitativni prístup a metody v psychologickém výzkumu. Praha: Grada.

Miovský, M., Skácelová, L., Čablová, L., Veselá, M., \& Zapletalová, J. (2012). Návrh doporučené struktury Minimálního preventivného programu prevence rizikového chování pro základní školy. Praha: Univerzita Karlova v Praze\&Togga.

Miovský, M., Skácelová, L., Zapletalová, J., \& Novák, P. (eds.). (2010). Primární prevence rizikového chování ve školství. Tišnov: Sdružení SCAN. 
MŠMT (2010). Metodické doporučení k primární prevenci rizikového chování u détí, žáků a studentů ve školách a školských zařizeních, č. j.: 21291/2010-28. Získáno 7. února 2018 z http://www.msmt.cz/vzdelavani/socialni-programy/metodicke-dokumenty-doporuceni-apokyny

MŠMT (2016). Statistická ročenka školství - Výkonové ukazatele 2015/16. Odbor školské statistiky, analýz a informační strategie. Získáno 7. února 2018 z: http://www.msmt.cz/vzdelavani/skolstvi-v-cr/statistika-skolstvi/statisticka-rocenka-skolstvi-vykonove-ukazatele

Neuwirth, J. (2012). Problematika evaluace minimálních preventivních programů na základních školách Jihočeského kraje. (Nepublikovaná bakalářská práce). České Budějovice: Jihočeská univerzita v Českých Budějovicích.

Pečinková, P. (2011). Analýza minimálně preventivního programu na základních školách. (Nepublikovaná bakalářská diplomová práce). Brno: Masaryková univerzita.

Pelcová, N. (2013). Hodnotová výchova a výchova k hodnocení. Pedagogika, 6, 285-300. Získáno z http://pages.pedf.cuni.cz/pedagogika/?p=1083\&lang $=$ cs

Pilařová, R. (2011). Tvorba preventivních programů na středních školách Havlíčkobrodska. (Nepublikovaná bakalářská diplomová práce). Brno: Masarykova univerzita.

Pražské centrum primární prevence. (2010). Manuál pro tvorbu minimálního preventivního programu. Získáno 1. ledna 2018 z chrome-extension://oemmndcbldboiebfnladdacbdfmadadm/http://www.msmt.cz/file/16437/download/

Rašková, M. (2008). Připravenost učitele k sexuálni výchově v kontextu pedagogické teorie a praxe v české primární škole. Olomouc: Univerzita Palackého v Olomouci.

Sadková, T. (2018). Současný stav sexuální výchovy v rámci základního vzdělávání v ČR systematický přehled teorie a praxe. Adiktologie, 18(1), 48-58.

Skácelová, L. (2010). Postup při zpracování minimálního preventivního programu: Primární prevence rizikového chování ve školství. Praha: VFN.

SPRSV (2017). Standardy pro sexuální výchovu v Evropě. Získáno 11. června $2018 \mathrm{z}$ https:// planovanirodiny.cz/storage/Standardy_pro_sexualni_vychovu_v_Evrope.pdf

Standardy pro základní vzdělávání - Člověk a jeho svět. Získáno 26. srpna 2018 z http://digifolio.rvp.cz/artefact/file/download.php?file=67494\&view $=9832$

Standardy pro základní vzdélávání - Výchova ke zdraví. Získáno 26. srpna $2018 \mathrm{z}$ http://digifolio.rvp.cz/artefact/file/download.php?file $=67503 \&$ view $=9832$

Šilerová, L. (2003). Sexuální výchova. Jak a proč mluvit s dětmi o sexualitě. Praha: Grada.

Šulová, L., Fait, T., \& Weiss, P. (2011). Výchova k sexuálně reprodukčnímu zdraví. Praha: Maxdorf.

UNESCO (2018). International technical guidance on sexuality education: An evidence-informed approach. Získáno 3. ledna 2018 z http://www.unaids.org/sites/default/files/ media_asset/ITGSE_en.pdf.

Výzkumný ústav pedagogický v Praze. (2005). Rámcový vzdělávací program pro základní vzdèlání s přilohou upravujicí vzděláváni žákì s lehkým mentálním postižením. Praha: VÚP.

Žlabová, L. (2013). Problematika tvorby minimálního preventivního programu pro ZŠ. (Nepublikovaná absolventská práce). Jabok: Vyšší odborná škola sociálně pedagogická a teologická.

Lubasová, T., Charvát, M., \& Taranzová, K. (2019). Obsahová analýza minimálních preventivních programů základních škol se zaměřením na témata sexuální výchovy. Psychologie a její kontexty, 10(2), 67-81.

https://doi.org./10.15452/PsyX.2019.10.0014 